\title{
In Vitro Maturation (IVM) of Human Oocytes: Promising Potential, Challenges and Chances for Improvement
}

\author{
Roza Silvia
}

\begin{abstract}
In Vitro Maturation (IVM) of human oocytes is an innovation in Assisted Reproductive Technology (ART). It is believed more patient-friendly than conventional In Vitro Fertilization (IVF) method. It is a simple protocol that needs only less injection of ovarian stimulation for the patients and fewer blood sample and ultrasound scans, so this technique may become more favorable. Patients are also prevented from higher cost treatments and quite long control in the hospital. However, there are some problems to be addressed, such as how to improve the success rate, how to assure the safety and to avoid the health risk for the offsprings. Modification in IVM medium and optimizing the IVM protocols have increased the results in some studies. However, further investigation related to all aspects influencing the human oocyte maturation in vitro is still needed to make it enable to be a routine practice in ART centers for a defined group.
\end{abstract}

Kata kunci: in vitro maturation, human oocyte, in vitro fertilization, assisted reproductive technology

\begin{abstract}
Abstrak
Maturasi oosit in vitro atau In Vitro Maturation (IVM) terhadap oosit manusia merupakan suatu inovasi dalam Teknologi Reproduksi Berbantu (TRB). Teknik ini dianggap lebih nyaman bagi pasien dibandingkan dengan metode Fertilisasi In Vitro (FIV) konvensional. Metode IVM ini sederhana dan hanya membutuhkan lebih sedikit penyuntikan obat stimulasi ovarium ke pasien serta lebih sedikit pemeriksaan darah dan ultrasonografi, sehingga memungkinkan untuk menjadi suatu pilihan yang disukai oleh pasien. Pasien juga bisa terhindar dari biaya terapi yang lebih mahal serta waktu kontrol yang lama di rumah sakit. Namun demikian, terdapat beberapa masalah yang perlu ditangani terkait metode ini, seperti bagaimana meningkatkan angka keberhasilan serta memastikan keamanan dan mencegah resiko kesehatan pada anak yang akan dilahirkan. Modifikasi pada medium IVM serta pengoptimalan protokol IVM telah meningkatkan hasil pada beberapa penelitian. Penelitian yang lebih mendalam terkait semua aspek yang mempengaruhi maturasi in vitro oosit manusia masih diperlukan menuju penerapan rutin prosedur IVM untuk kelompok pasien tertentu di pusat-pusat pelayanan TRB.
\end{abstract}

Keywords: maturasi in vitro, oosit manusia, fertilisasi in vitro, teknologi reproduksi berbantu

Affiliasi penulis: Bagian Histologi Fakultas Kedokteran Universitas Andalas Padang

Korespondensi: Roza Silvia, E-mail;roza.silvia_md@yahoo.com, Telp: 0751497982

\section{INTRODUCTION}

In vitro maturation (IVM) of oocytes is an emerging technique that allows immature oocytes retrieved from females to reach their maturation in the artificial medium outside of the natural condition. It can be applied either in natural or stimulated ovarian cycle.
For human application, however, unstimulated ovarian cycle becomes an interesting choice, especially for women with high risk of ovarian hyperstimulation syndrome (OHSS). In fact, this method was initially applied in human as alternative procedure to get mature oocyte without risk of OHSS in patients with polycystic ovarian syndrome (PCOS). However, through its development, IVM for human oocytes can be used for several purposes. ${ }^{1,2}$

Although it provides some promising benefits, but over the past decade, the achievement of this 
technique is still suboptimal. The absence of risk for OHSS, cost efficiency and comfortable method for patients have been considered as the positive points of IVM. In contrast, it is still not applied regularly in assisted reproductive treatment (ART). Its success rate in human reproduction is also still limited. IVM oocytes are believed still prematurely developed. Furthermore, it seems that people have not fully understood about all aspects that may influence the outcomes. In addition, how to optimize the success rate is still remains unclear. ${ }^{1,3,4}$

It still becomes a critical challenge to reveal the factors contributing the competence of in vitro oocyte maturation and how to control the process. It is believed that the success of IVM is related to the combined nuclear and cytoplasmic maturation of the oocytes. Several approaches have been taken to gain more understanding about the mechanism, including the studies on the composition of maturation medium and how to improve the IVM protocols. However, previous studies still have not succeeded to explain clearly the process and detailed contributors toin vitro maturation oocyte. .,2,4 $^{1,4}$

\section{EARLY DEVELOPMENT AND PROMISING POTENTIAL OF IVM FOR HUMAN}

IVM came as an improvement to classic methods of in vitro fertilization (IVF) for a certain group of patients. It is basically an innovation to grow immature oocytes to reach the stage of metaphase II.During its development, IVM for human oocytes seems to be a promising alternative to conventional IVF procedures because of several advantages. Therefore, talking about IVM cannot be separated from the history of IVF development. ${ }^{1,2}$

Pincus and Enzman in 1935 were the first scientists who proved the capability of immature rabbit oocyte, as the model of mammalian oocytes, to gain its maturation after removing from the follicle. For human oocytes, Edwards and colleagues were the pioneers in the experiments of IVM. In 1965, they were success to mature human oocytes in a culture medium, and in 1968, they reported the accomplishment of in vitro fertilization (IVF) for in vitro matured human oocyte. ${ }^{1,4,5}$

Since IVF technique was developed in midnineteenth century, a lot of innovation and improvement have been gained regarding the applicability of this method on animals as well as human reproductive. At first, IVF in human was performed without an initial ovarian stimulating treatment and only used a single oocyte retrieved from the natural cycle. Along with its development, stimulated cycles were elaborated to yield more oocytes. $^{2}$

Ovarian stimulation which is usually used to produce more mature oocytes, seems not entirely safe. It is also clearly associated with a high risk of OHSS in females involving treated with IVF. Although the range of its reported incidence is between $0.5 \%$ $14 \%$, but some patients with OHSS may end up with a severe condition, and even fatal, especially if they have PCO and PCOS. It is believe that the best way to avoid OHSS is by avoiding the ovarian superovulation. Therefore, the best option to yield more number of human oocytes safely has become an issue since several decades ago.,

In vitro maturation (IVM) of oocytes presents another way to produce more mature oocytes without depending on a set of ovarian stimulating procedures. In IVM, preliminary ovarian stimulations are not really needed, although some doctors still perform a short stimulation. It provides a better hope, especially for women with PCO and PCOS, to lower or even abolish the risk of OHSS. In this method, immature oocytes are collected from the follicles, and then their maturation is reached in an artificial medium that is modified to mimic the natural condition in the ovary. Even though this strategy now can be used for several reasons in clinical aspects, but this strategy was initially aimed for the patients with PCO with a risk of OHSS. IVM is also considered as a patient-friendly method. Patients are not required to have a routine injection for a certain time, as administering in stimulated cycles. They also do not need to be closely controlled in the clinics or hospitals, as applied in ovarian stimulating protocols, to avoid OHSS. Therefore, the cost the patients should pay 
may also be lowered. ${ }^{8-11}$

IVM technique nowadays is also combined with the ovarian cryopreservation for the patients suffering from any cancers that may interfere their reproductive organs. Oocytes can be cryopreserved from any stages of development and from any ages except post-menopausal, therefore, female cancer patients have more chance to maintain their fertility for even after chemotherapy or radiotherapy is performed. IVM is suggested as one method to harvest the mature oocytes later on, and then IVF can be carried out to assist the reproduction. Therefore, it is also considered as the best choice for these patients to preserve their fertility in long term purpose. ${ }^{8,10}$

\section{CHALLENGES OF IVM APPLICATION FOR HUMAN OOCYTES}

IVM of human oocytes still meets some challenges. Its application is still limited and has not been a routine practice in ART yet, although it has been being developed for about 40 years. Although various studies have been conducted in many centers to find out the most suitable approach in IVM application on human oocytes, but it seems that the results on human oocytes are still poor. From study by Trounson et al in 1994, only twenty percent of all unovulatory PCOS patients involved in that project presented a healthy pregnancy and born an alive baby from the fertilized IVM oocyte. Besides, the safety issue of the offspring's health still becomes a concern and debatable matter.These things may lower the intention to put IVM as the regular choice for infertile patients. Basically, how to improve the success rate and to assure there are no health-related risks on the children conceived through IVM procedure are the main challenges in IVM practice for human nowadays. $^{2,9,12-14}$

The quality of IVM medium is important for the accomplishment of IVM in human. It seems still difficult to endure the intrafollicular maturation program for the next couple days in vitro, resulting in a poor rate of live offspring produced for human. To provide a suitable artificial medium for human oocyte maturation in vitro is still under continuous studies until now. The best medium composition is still unclear. Also, it is still difficult to create the similar condition in vitro with the real ovarian follicular environment. However, as for any other species undergoing IVM, the appropriate condition of this synthetic medium is really needed for human oocyte maturation, and also to support the oocyte potential for fertilization and further embryo development. ${ }^{11,13-15}$

The certainty that all processes of oocyte growth have been achieved is also important for the success of IVM. Oocyte maturation is considered as the climax of a long process in oocyte growth from female germ cells. Oocyte maturation should reach both nuclear and cytoplasmic maturation. Nuclear maturation is defined as the ability of oocytes to continue meiosis and develop from prophase I to metaphase II. Following resumption of meiosis, germinal vesicles breakdown and nuclear membrane dissolves. Separated homologous chromosomes then is extruded into periviteline space, becoming first polar body. After that, through second meiosis, oocytes reach the stage of metaphase II. Meanwhile, cytoplasmic maturation is characterized by some ultrastructural and biochemical changes in oocyte cytoplasm that are necessary for fertilization and further embryo development. It is believed that there is a significant increase in oocyte cytoplasmic organelles and structures during its maturation process, such as cortical granules. All of these things should occursychronizedly during oocytes maturation. And any aberrations or deficiencies within those processes may result in either fertilization block or implantation failure. ${ }^{16-19}$

Even though nuclear maturation may happens spontaneously when inhibitor signal in follicles is suppressed, it does not guarantee that cytoplasmic maturation will present correctly. Studies on mice oocytes suggested that most problems with oocyte maturation are associated with cytoplasmic reprogramming rather than aberrations in meiosis. Furthermore, its effect is rarely detectable during the early stage of oocyte development, but more frequently manifested in the stages of late cell-division and peril-implantation. Therefore, follow-up of postfertilization development should be a valid indicator for oocyte developmental competence. ${ }^{17-19}$

Obviously, cytoplasmic maturation combined simultaneously with nuclear maturation is also required 
for successful oocyte maturation in vitro. The less competence in cytoplasmic maturation of IVM oocyte compared to in vivo matured oocyte is highlighted as the cause of low blastocyst rates of IVM oocytes although they present the good nuclear maturation. Some studies showed results that there are no significant differences regarding nuclear maturation between in vivo and in vitro matured oocytes. The oocytes derived from both ways of maturation show almost the same rates of fertilization and cleavage. However, clinically embryonic developmental was poor; with only $18 \%$ of pregnancy rate and $40 \%$ of them had early miscarriage. ${ }^{4,12,14,15}$

Regarding the safety issue, there are only few studies about IVM safety on human related to the health status of the children born following IVM. In general, current data shows an increase of health problems in children conceived through ART. They are related to chromosomal anomalies, major congenital malformation, and imprinting disorders. But is not clear whether it is really due to the method of ART used or the underlying diseases of the parents that cause infertility problems. ${ }^{2}$ According to a study by Buckett et al in 2007, there is no significant difference regarding baby's congenital abnormality between normal conception and ART. In addition, the cases are lower for IVM than for ICSI, although ICSI is used in all IVM. The explanation for this condition can be due to abnormal sperm that may be used in ICSI, not fully due to the method itself. Other studies by Shu-Chi et al in 2006 and Soderstom-Antitla et al in 2006 also suggested that chromosomal constitution and mental development were not significantly different between IVM and spontaneously conceived children. 2,12,14,15

It seems that the safety and health-problem risks of IVM really depends on the ability of the oocytes to gain nuclear and cytoplasmic properly in vitro, and also the selection of sperm used in ICSI for IVM oocyte. If the IVM and IVF procedure are done correctly, no worries on health and safety issue are needed. Available data currently likely to reassure that IVM is quite safe and no need to worry regarding issue of congenital malformations, physical or neurological developmental delay. ${ }^{2}$

\section{CHANCES FOR IMPROVEMENT}

Some studies on IVM for human oocytes have identified several strategies to improve the success rate, and the possibility to have it as a routine practice for a defined group of patients. Some are related to IVM media modification and patient selection criteria, while other studies are based on oocyte quality and endometrium preparation. Including here are $\mathrm{FSH}$ priming, follicles selection and hormone therapy for endometrium. ${ }^{3,7,10}$ However, not all of these have been fully understood and gained general agreement. Some are still debatable and require further research.

Although not many studies based on human regarding IVM media, but some suggested the benefit of gonadotrophin and protein supplementations. Adding $\mathrm{FSH}$ and $\mathrm{LH}$ into IVM and culture media is believed to increase the oocyte maturation and embryo cleavage in vitro. Meanwhile, another study showed the significant increase in maturation, implantation and clinical pregnancy rates when immature human oocytes were matured in IVM medium with $10 \%(\mathrm{v} / \mathrm{v})$ maternal serum addition compared to $2 \%(\mathrm{w} / \mathrm{v})$ human serum albumin (HSA). Nevertheless, further studies are still needed regarding the best concentration of the media compositions. ${ }^{7,9,11}$

The patient's characteristic may influence the result of IVM, therefore a careful selection of the patients for IVM is a necessity. It has been well known that young-aged women undergoing IVM, as any other ARTs, may have a better result than the older ones. Age of 35 is assumed to be the borderline. Some believe that regularity of the women's cycle may also affect the outcome. Although at the earlier time of IVM application on human it was indicated for irregular cycle and anovulatory women with PCOS, but Mikkelsen et al in 1999 pointed out that normoovulatory young women showed better endpoint. On the other hand, others suggested that young women with PCO and PCOS are the best choice for IVM, because they have more antral follicles available. However, generally it is agreed that young women attempting IVM may have a better outcome. ${ }^{15,16,20}$

Regarding FSH priming, some studies agreed that pretreatment with $\mathrm{FSH}$ during the early follicular 
phase is useful to improve the result of IVM by having more oocytes retrieved, while others disagreed. In 1998, Wynn et al stated that FSH priming can promote the number of mature oocyte in vitro. Besides, study by Mikkelsen and Lindenberg in 2001 have showed the improved pregnancy and implantation rate in women with PCOS after FSH priming $150 \mathrm{IU}$ per day for 3 days and retrieving oocyte 2-3 days later when follicles reached $10 \mathrm{~mm}$ in size, whereas there was no improvement found when this method was applied to women with regular cycles. Similar to this result, the study by Junk and Yeap in 2012 also found the benefit of FSH priming in term of improving oocyte viability and subsequent development of embryo in PCOS patients. ${ }^{2,3,7,16}$

Another thing that may improve the success of IVM is timing for immature oocyte retrieval. A study by Junk and Yeap in 2012 suggested the ideal time is when follicle size has been $10-12 \mathrm{~mm}$. It is related to the oocyte competence that may impact the embryo developmental potential. But, it is still a matter of debate. Some others claimed it is better to retrieve oocytes from smaller size follicle due to the possibility of the non-dominat follicles, especially in unstimulated cycle, to experience early atresia., ${ }^{3,6,7}$

Beside those things above, endometrial preparation is also suggested to improve IVM success rate for human application. It is important to have uterus ready for implantation and subsequent pregnancy. In general practice, estradiol is used since the day of oocyte retrieval. The dosage is determined by endometrial thickness, ranging between $6-10 \mathrm{mg}$ per day. Progesterone is also given as $200 \mathrm{mg}$ every 8 hours, started on the day of fertilization until 12 weeks of pregnancy. ${ }^{6}$

A study by fertility specialists in Western Australia in 2012 claimed that a better success rate of IVM for human oocyte can be achieved by optimizing the IVM protocol as they proposed. Based on their prospective cohort study on women with PCO and PCOS seeking for infertility treatment in their hospital, they found the increased implantation, clinical pregnancy and live-birth rates. They did FSH priming to the patients (100 IU or $150 \mathrm{IU}$ ) for 3 days and selected follicles for aspiration whose size is 10 to 12 $\mathrm{cm}$. Unlike the most current protocol of hormonal therapy for endometrial preparation, estrogen was given earlier, initialed 2 days before oocyte retrieval. And finally, they performed blastocyst-stage singleembryo transfer. However, the study showed that oocyte maturation and fertilization rates were similar to the previous studies in human clinical infertility treatment. ${ }^{3,20}$

\section{REFERENCES}

1. Gilchrist RB, Thompson JG. Oocyte maturation: emerging concepts and technologies to improve developmental potential in vitro. Theriogenology. 2007;67:6-15.

2. Ata $B$, Reibblatt $S$, Tan SL. In vitro maturation. In: Kovaks G (editor). The subfertility handbook, a clinician's guide. $2^{\text {nd }}$ edition. New York: Cambridge University Press; 2011. pp. 135-47.

3. Junk SM, Yeap D. Improved implantation and ongoing pregnancy rates after single-embryo transfer with an optimized protocol for in vitro oocyte maturation in women with polycystic ovaries and polycystic ovary syndrome. Fertility and Sterility. 2012;98(4):888-92.

4. Miron P. In-vitro maturation of oocytes: biological aspects. Reproductive BioMedicine Online. 2006:13(3);437-46.

5. Shalom-Paz E, Holzer H, Son W-Y, Levin I, Tan $\mathrm{SL}$, Almog B. PCOS patients can benefit from in vitro maturation (IVM) of oocytes. European Journal of Obstetrics \& Gynecology and Reproductive Biology.2012;165(1):53-6.

6. Papanikolaou EG, Tournaye H, Verpoest W. Early and late ovarian hypersimulation syndrome: early pregnancy outcome and profile. Human Reproduction. 2005;20:636-41.

7. Holzer HEG, Chian R-C, Demirtas E, Ba-Akdah H, Tan SL. In vitro maturation of oocytes. In: Gardner DK (editor). In vitro fertilization, a practical approach. New York:Informa Healthcare; 2007. pp. 127-45.

8. Abir R, Nitke S, Ben-Haroush, Fisch B. In vitro maturation of human primordial ovarian follicles: clinical significance, progress in mammals, and methods for growth evaluation. Histol Histopathol. 
2006;21:887-98.

9. Albuz FK, Sasseville M, Lane M, Armstrong DT, Thompson JG, Gilchrist RB. Stimulated physiological oocyte maturation (SPOM): a novel in vitro maturation system that substantially improves embryo yield and pregnancy outcomes. Human Reproduction. 2010;25(12):2999-3011.

10. Lanzerdorf SE. The developmental potential of in vitro- and in vivo-matured human oocytes collected from stimulated and unstimulated ovaries. Fertil Steril. 2006;85:12-8.

11. Piquette GN. The in vitro maturation (IVM) of human oocytes for in vitro fertilization (IVF): is it time yet to switch to IVM-IVF? Fertil Steril. 2006;85:833-5.

12. Buckett WM, Chian RC, Holzer H. Obstetric outcomes and congenital abnormalities after in vitro maturation, in vitro fertilization, and intracytoplasmic sperm injection. Obstet Gynecol. 2007;110:885-91.

13. Coticchio G, Dal-Canto M, Guglielmo M-C, MigniniRenzi M, Fadini R. Human oocyte maturation in vitro. Int. J. Dev. Biol. 2012;56:909-18.

14. Shu-Chi M, Jiann-Loung H, Yu-Hung L. Growth and development of children conceived by in-vitro maturation of human oocytes. Early Hum Dev. 2006;82:677-82.

15. Soderstom-Anttila V, Salokorpi T, Pihlaja M, Serenius-Sirve S, Suikkari AM. Obstetric and perinatal outcome and preliminary results of development of children born after in vitro maturation oocytes. Hum Reprod. 2006;21: 150813.

16. Torre A, Anchour-Frydman N, Feyereisen E, Fanchin R, Frydman R. How do we improve implantation rate following in-vitro maturation of oocytes? In: Tan SL, Chian R-C, Buckett WM (editors). In-vitro maturation of human oocytes, basic science to clinical application. London: Indofarma Heathcare; 2007. pp. 319-31.

17. Li Y, Feng H-L, Cao Y-J, Zheng G-J, Yang Y, Steve $M$, et al. Confocal microscopic analysis of the spindle and chromosome configurations of human oocytes matured in vitro. Fertil Steril. 2006;85:827-32.

18. Trimarchi JR, Keefe DL. Assessing the quality of oocytes derived from in vitro maturation-are we looking under the lamppost? Fertil Steril. 2006;85:122-9.

19. Vanhoutte L, Nogueira D, Sutter P. De. Prematuration of human denuded oocytes in a three-dimensional co-culture system: effects on meiosis progression and developmental competence. Human Reproduction. 2009;24(3):658-69.

20. Son WY, Lee SY, Yoon SH, Lim JH. Pregnancies and deliveries after transfer of human blastocysts derived from in vitro maturation cycles. Fertility and Sterility. 2007;87:1491-3. 